\title{
Funds Manager and Mutual Funds Characteristics on Mutual Funds Performance: Empirical Evidence of Equity Mutual Funds in Indonesia
}

\author{
Rina Rachmawati ${ }^{1,2}$, Sugeng Wahyudi ${ }^{1}$, Irene Rini Demi Pangestuti ${ }^{1} \&$ Najmudin $^{3}$ \\ ${ }^{1}$ Faculty of Economics and Business, Diponegoro University, Semarang, Indonesia \\ ${ }^{2}$ Faculty of Engineering, Semarang State University, Semarang, Indonesia \\ ${ }^{3}$ Faculty of Economics and Business, Jenderal Soedirman University, Purwokerto, Indonesia \\ Correspondence: Rina Rachmawati, PhD Candidate in Economics, Diponegoro University, and Senior Lecturer at \\ Faculty of Engineering, Semarang State University, Sekaran Str., Semarang City, 50229, Central Java, Indonesia. \\ E-mail: rinarkamal@gmail.com
}

Received: October 21, 2019

Accepted: November 15, 2019

Online Published: March 16, 2020

doi:10.5430/ijfr.v11n2p77

URL: https://doi.org/10.5430/ijfr.v11n2p77

\begin{abstract}
This study examines the effect of investment fund managers' characteristics in the form of tenure, and mutual fund characteristics with proxy turnover portfolios, market timing and stock selectivity on the performance of stock mutual funds. The research sample is 27 stock mutual funds in Indonesia that were active from 2013 to 2017. On the analysis of the relationships between the characteristics of investment managers and mutual funds characteristics on the performance of stock mutual funds, a series of OLS regressions were run. The panel data regression was included based on using the Eviews. All of the above were aimed at achieving portfolio optimization and realizing the maximization of the interests for fund management companies and investors. The main findings are as follows. Tenure does not affect the performance of stock mutual funds during the years 2013 to 2017, but if divided into 2 quadrants of tenure, namely tenure over 19 years and tenure under 19 years of work, the result is that tenure over 19 years has a positive effect on the performance of stock mutual funds, but tenure brought 19 years has no effect on the performance of equity funds, whereas mutual funds characteristics, which are proxied by portfolio turnover, market timing and stock selectivity, have a significant positive effect on the performance of equity funds in Indonesia. The primary limitation in the scope is the sample, because stock mutual funds that publish consistently Financial statements between 2013 and 2017 are few in number. These findings have important implications for fund management companies as input material that the investment strategy of the investment management team affects the performance of equity funds compared to the characteristics of investment managers with proxies for years of service. This paper proposes a new perspective to evaluate the relationship between the fund manager and mutual funds characteristics and divide 2 groups of working years, and calculate them with non-linear models.
\end{abstract}

Keywords: tenure, turnover portfolio, market timing dan stock selectivity, mutual funds performance, markowitz

\section{Introduction}

The development of the mutual fund industry in Indonesia is increasing in line with the development of investment in the capital market and the growth of the Indonesian economy. An improving economy and followed by investment developments in Indonesia, will spur investors who do not have the expertise to invest in mutual funds (Pangestuti et al. 2017). Increased mutual fund investment can be seen from the number of Asset Under Management (AUM) which reached Rp 493.65 trillion as of August 31, 2018, an increase of 222 trillion from 2015 (The Service and Financial Authority, 2019). In Indonesia, equity funds have the most significant development compared to other types of mutual funds, because equity funds produce the highest returns. The average return on equity funds from January to August 2016 has always been positive and recorded a return of $16.52 \%$, and in 2017 continues to strengthen, starting from April 20, 2017 the average of mutual fund shares is able to record a year-to-date performance of $2.22 \%$. 
Table 1. Equity funds compared to the Composite Stock Price Index (CSPI) (2013 - 2017)

\begin{tabular}{llllll}
\hline No & Year & $\begin{array}{l}\text { Asset Under management } \\
\text { stock mutual funds }\end{array}$ & NAB/UP & $\begin{array}{l}\text { Stock mutual } \\
\text { fund returns }\end{array}$ & Return market \\
\hline 1 & 2013 & 87.120 .048 .247 .172 & 1816,313 & 13 & 20,2 \\
\hline 2 & 2014 & 112.023 .528 .143 .910 & 1865,331 & 21,3 & 22,3 \\
\hline 3 & 2015 & 109.985 .614 .261 .956 & 1477,739 & $-14,5$ & $-12,1$ \\
\hline 4 & 2016 & 121.493 .735 .749 .299 & 1414,110 & 7.7 & 15.3 \\
\hline 5 & 2017 & 137.638 .725 .425 .599 & 1628,556 & 2,2 & 19,9 \\
\hline
\end{tabular}

The increase in mutual fund investment is due to the ease of investing in mutual funds and the level of return and risk of mutual funds. The ease of investing in mutual funds because of the assistance for investors who do not have the expertise to invest by involving a third party called the Investment Manager. In causal financial statements of mutual funds in Indonesia, investment managers are divided into 2 components of the team, namely the investment committee and the investment management team. The performance of mutual funds is highly dependent on the characteristics of investment managers and the characteristics of mutual funds (Maestri and Malaquias 2018). The characteristics of investment managers and the characteristics of mutual funds will affect mutual fund performance. Investors will invest their money by taking into account: resource management by specialized professionals, the possibility of liquidity, portfolio diversification, and superior/abnormal expected returns (Laes and daSilva 2014; Nanda et al. 2000). In this study the indicator of resource management by specialized professionals is the tenure variable, which indicates the experience of employees in terms of employee tenure. The experience of managers shows their ability in the sphere of knowledge about mutual fund investment (Li et al. 2011). In accordance with the theory of human capital, that the ability of company employees is the company's capital in improving company performance. The ability of these employees can be indicated by the experience of employees, while work experience is identical to their working years working in the field. Tenure is human capital which includes: knowledge, skills and abilities that can be used by someone to produce good performance (Harris 2009). Human resources consist of education, skills and experience (Auw 2009) and in management will improve company performance (Patterson et al., 1996).

Indonesia is a weak efficiency market (Lubis and Ismail 2010), so there is still information in the market that is not well publicized. This provides an opportunity for investors to obtain abnormal returns by applying the right investment strategy. By looking at market conditions in Indonesia, the right investment strategy is an active investment strategy. An active investment strategy is an active strategy in investing in order to adjust market conditions so that you will get a higher profit. Mutual fund investment strategies consist of portfolio turnover, market timing and stock selectivity. The level of portfolio turnover which is proxied by turnover ratio shows the activeness of investment managers in managing mutual funds and has an aggressive nature (Narayanamoorthy et al. 2012). Based on previous research, portfolio turnover, market timing and stock selectivity are inconsistent in increasing mutual fund performance. portfolio turnover has a positive impact on investment managers' performance (Manek 2016; Cremers and Pareek, 2016; Dyck et al. 2013; Pástor et al. 2015; Kremnitzer 2012; Brinson et al. 1996; Dahlquist et al. 2000; Wermer 2000; ; Cremers and Petajisto 2009; Grinblatt and Titman 1993; Ippolito 1989). However, there are some studies that explain that portfolio turnover negatively affects investment performance (Champagne et al. 2018; Pástor et al. 2015; Wu 2014; See and Jusoh 2012; Rao 2010; Khorana et al. 2002; Carhart 1995). Some studies have suggested that tenure has a positive effect on mutual fund performance (Hu and Chang 2008; Persson and Karlsson, 2005; Poole et al. 2006; Lee et al. 2008; Philpota et al. 2000; Payne et al. 1999; Golec 1996). But other studies suggest that tenure is negatively related to mutual fund performance (Malaquias and Junior 2014; Naidenova et al. 2015; Porter and Trifts 2012).

In Indonesia, there is also research inconsistency, active strategies will get higher returns than buy and hold strategies (Khajar 2011), but Putra et al. (2013) state that the active strategy obtains a lower return value compared to using a passive (hold and buy) strategy, this happens in the Indonesian market conditions that are currently in good condition (bullish). Meanwhile, if Indonesia's capital market conditions are bad (bearish), then the passive strategy (buy and hold) will get a worse return compared to the active strategy (Putra et al. 2013). Other studies argue that fund trading hurts performance because it will increase the value of high expense, this will increase the risk borne so that it will reduce the return obtained (Manurung, 2012). This study will examine the fund manager's tenure that affects mutual 
fund performance and investment strategies that improve mutual fund performance, with investment strategies proxied as portfolio turnover, market timing and stock selectivity. The study used a sample of stock mutual funds in Indonesia during the 20132013 study. The results showed that the years of service had no effect on mutual fund performance. The working period indicates that if the tenure is high then the ability of employees is not proven. This study then divided the 2 working-age groups into group 1, which was tenure under 19 years, and group 2 was tenure over 19 years. The division of groups is based on non-linear relationships so as to get an extreme point of 19 years. The results show that work tenure over 19 years has a significant positive effect on mutual fund performance, but not with tenure under 19 years. The results of the study of the influence of investment strategies with portfolio turnover proxy, market timing and stock selectivity have a significant effect on the performance of equity funds in Indonesia.

\section{Literature Review}

\subsection{Theory of Modern Portfolio and Indonesia Mutual Fund}

The theory underlying investment diversification to minimize risk and increase investment returns (return) is known as the modern portfolio investment theory that was first coined by Harry Markowitz (1952). The concept of Markowitz's theory is "Don't put all your eggs in one basket". Investment instruments that apply the principle of investment diversification are mutual funds. PT Danareksa is the first mutual fund company in Indonesia, established in 1976 by issuing Danareksa certificates for the initial issuance of mutual funds. Pursuant to Law No. 8/1995, mutual funds are defined as a place used to collect money from investors and then invest in securities portfolios by Investment Managers who have received permission from the Financial Services Authority. Mutual funds are a form of investment by collecting various investments in various securities (Kapoor 2010). In general, mutual funds or mutual funds are premium investment places to invest in the form of securities portfolios, which are then reflected in the Net Asset Value per unit of participation (the Financial Services Authority (OJK).

The performance of mutual funds is the main thing that investors see when investing. The fund's performance is influenced by several factors, both internal and external. The most influential factor is the characteristics of mutual fund investment managers and mutual funds characteristics, this is because mutual funds involve third parties, namely investment managers.

In line with Markowitz's theory where investments with high risk will produce high returns, Equity Funds are mutual funds that have the highest level of return and risk compared to other types of mutual funds. In Indonesia, Equity Funds are the type of mutual funds most favored by investors compared to Balance Funds, Fixed Income Funds, Money Market (the Financial Services Authority/OJK).

Table 2. Asset values of several types of mutual funds in Indonesia

\begin{tabular}{llll}
\hline Types & Amount & Asset Values (in IDR) & Equal values in USD \\
\hline Equity Funds & 274 & $124,846,600,441,984$ & $8,781,809,877$ \\
\hline Money market funds & 282 & $38,519,111,145,860$ & $2,709,465,131$ \\
\hline Fixed income mutual funds & 213 & $1,902,210,881,751$ & $133,803,037$ \\
\hline Mix mutual funds & 177 & $21,115,311,316,596$ & $1,485,267,911$
\end{tabular}

Source: the Financial Services Authority (OJK), processed, 2018

Based on a comparison of data on stock mutual funds returns with the benchmark (CSPI) it is known that mutual fund returns returns fluctuate each year. Returns on mutual funds in 2015 were negative, while positive returns in 2013, 2014, 2015 and 2017. In 2014 equity funds posted the best return of 21\%. Judging from the data above, the performance of equity funds is very volatile and overall the performance of equity funds in 2013-2017 has not been able to surpass the benchmark (CSPI). The condition of return that has not been able to beat the benchmark, is feared to have an impact on declining investor interest in investing in mutual funds. so the problem arises is what factors affect the performance of equity funds in Indonesia? The benefits of the results of this study will be a reference for investment managers about what things or variables can be developed to improve the performance of equity funds in Indonesia.

The Indonesian capital market is a weak efficient capital market because it is still an emerging market (Lubis and Ismail 2010). In accordance with the theory of market efficiency (efficiency market hypothesis), which states that 
asset price movements follow unpredictable patterns, and the difficulty of predicting stock price movements for a short period of time (Fama 1970), the investment manager adopts an investment strategy that always changes the composition of investment portfolio in order to adjust random market prices and get optimal returns (Lubis and Ismail 2010).

\subsection{Portfolio Tenure, Turnover Portfolio, Market Timing, Stock Selectivity and Mutual Funds Performance}

The tenure of an investment manager committee (tenure) relates to a person's experience in the mutual fund investment industry. The theory that underlies the tenure relationship of mutual fund investment committee members and mutual funds performance is Resources Based Theory (RBT). This theory emphasizes the ability of the company's resources to increase value added for the company, so the company will be able to perform well. Human resource capability can be measured by the years of service of employees (Petty and Guthrie 2000). Shortly, tenure is a time-based process of understanding the external and internal environment. Therefore, longer tenure is synonymous with experience and knowledge of higher work. So if the tenure is high, the investment manager has a higher commitment to what he does so that it will affect the company's performance (LiU and Ravichandran 2007). And high tenure indicates that fund managers are able to avoid risks (Scott 2010). From the explanation above shows that high tenure shows that fund managers are able to control mutual funds well so that mutual fund performance is getting better.

A profitable portfolio is a portfolio that is managed by adjusting market conditions, and investment strategies are needed to adjust market conditions that are not efficient in order to obtain optimal returns, including portfolio turnover, market timing and stock selectivity. Portfolio turnover is defined as a measure of the average securities traded by portfolio managers over a period of time, or how often investment managers exchange mutual fund assets in an effort to obtain optimal returns and or outperform their benchmarks, and portfolio turnover ratios are used to calculate how active investment manager in portfolio rebalancing (Rao 2010). Asset price movements that cannot be predicted due to new information in the market, force investment managers to make transactions and adjust the portfolio composition in the hope of increasing returns. This step is in line with strategic active management, namely conducting investment evaluation activities in the form of rebalancing activities. The portfolio turnover ratio can also be used as: 1) investment managers 'efforts to increase mutual fund managers' added value, 2) detecting undervalues and overvalues of mutual fund values, 3 ) as one of the considerations for investment managers to make decisions about selling or buying (de Mingo-López and Matallín-Sáez, 2018).

Market timing is a strategy to respond to changing markets, by changing the composition of portfolio in securities that have low volatility or doing the opposite activities (Baker et al. 2010). Mutual fund managers can market time liquidity and their timing abilities can predict future fund performance (Cao et al. 2013). Stock selectivity is an investment strategy seen from the ability of investment managers in choosing the appropriate securities into the portfolio composition. Stock selectivity is positively related (positive $\alpha$ ) to firm performance (Hochberg and Muhlhofer 2011; Brinson et al. 1996). Market timing is a fund manager strategy to choose the right time to change the composition of the portfolio, the goal is to maximize the profits of mutual funds. There is an inconsistency of Market timing's relationship with mutual fund performance. Market timing will increase mutual fund performance (Treynor et al. 1966; Brinson et al. 1996). But there is previous research that is a negative relationship between market timing and stock selectivity on mutual fund performance (Swinkels and Rzezniczak 2009). Stock selectivity is an investment strategy seen from the ability of investment managers in choosing the appropriate securities into the portfolio composition. Stock selectivity is positively related (positive $\alpha$ ) to firm performance (Hochberg and Muhlhofer 2011; Brinson et al. 1996). Based on the market efficiency theory (Efficiency Market hypothesis) that changes in the price of past securities cannot be used as estimates of future stock prices (Fama 1970). In response to this, the investment manager rebalances the securities portfolio in the hope of getting a return. Investment managers try to adjust the composition of the securities portfolio based on the new information by implementing an active strategy (Henriksson and Merton, 1981). That attitude is outlined in the Market timing and Stock selectivity investment strategies.

\section{Data Description and Methodology}

The type of research used was causalitas research with quantitative approach. While The population of equity mutual funds registered in the Financial Services Authority (OJK). Based on the latest data from OJK in 2013 up to 2017, the population of equity mutual funds during the period were 134 equity mutual funds. However, not all 134 equity mutual funds would be used in this study sample. The sampling technique used was a purposive sampling technique. The criteria applied in this research were that sample selection in this study based on several criteria, among others (1) the equity mutual funds routinely publishes financial statements as of year 2013 up to year 2017 ; (2) the equity 
mutual funds has information relating to various measurement variables, such as: tenure, turnover portfolio, and Net Asset Value (NAV). Data source in this research is web and Bloomberg investment manager. Based on these criteria, the number of samples used was as many as 27 equity mutual funds.

This research data used a secondary data type obtained from published sources. The required data were the monthly data of Net Asset Value (NAV) of each equity mutual funds and interest rate during the 2013-2017 period. The data on tenure and turnover portfolio were obtained from Investasi's ManagerProspektuc, The data on market return and the risk free rate data were obtained from Bank Indonesia. Equity mutual funds return, risk-free rate of return, standard deviation were important to calculate the Sharpe Index. Endogenous variable in this study is mutual funds performance by sharpe ratio measured by the sum of mutual funds's return and market return divided by standart deviation. The performance measurement method applied used measured the performance with the Sharpe methods (Pangestuti et al. 2017; Robiyanto et al. 2019). The Sharpe Index value is used as a proxy for mutual funds performance because it considers systematic and unsystematic risk. Exogenous variables in this study are tenure, portfolio turnover, market timing and stock selectivity. Tenure was calculated from the time since the member was added to the fund manager. Portfolio turnover which is measured using the lowest sale or lowest purchase divided by the net asset value of the mutual fund. Market timing and Stock selectivity are calculated using measurements popularized by Treynor and Mazuy (Treynor et al. 1966).

In this study, there are one regression panels used. That is, the characteristics of investment managers with the tenure acronym, the characteristics of mutual funds with the Turnover portfolio acronym, Market timing acronyms and Stock selectivity acronyms. The panel regression model used is independently pooled panel because there are no unique attributes of individuals within the measurement set and no universal effects across time.

The measurement of mutual fund performance variables as the dependent variable is the Sharpe Ratio method, which is often also called the reward-to-variability ratio. The calculation using the Sharpe method was chosen for several reasons, including: 1) considered to be the most reliable in the Indonesian market, and 2) the sharpe method takes into account the systematic and unsystematic risk that is proxied in the standard deviation, and 3) the Sharpe Index is used to measure the magnitude of additional profits investment received by the investor (risk premium) is proportional to the risk that goes with it (Wiksuana 2009).

Sharpe ratio index measurement is as follows:

$$
\text { Sharpe Ratio }(\mathrm{Sp})=\frac{\left(\mathrm{R}_{\mathrm{p}}-\mathrm{R}_{\mathrm{f}}\right)}{\sigma_{\mathrm{x}}}
$$

In which

$\mathrm{Sp}=$ Sharpe mutual fund performance

$\mathrm{X}=$ mutual funds

$\mathrm{R}_{\mathrm{p}}=$ average mutual fund return

$\mathrm{R}_{\mathrm{f}}=$ central bank rate (as free risk rate)

$\sigma_{\mathrm{x}}=$ standard deviation of mutual funds.

With the measurement of the average investment return on mutual funds (Ferreira et al., 2012)

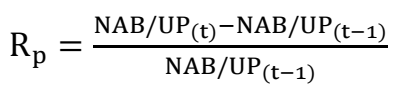

In which:

$\mathrm{R}_{\mathrm{p}}=$ Stock mutual fund returns in the year $\mathrm{t}$

$\mathrm{NAB} / \mathrm{UP}_{(\mathrm{t})}=\mathrm{NAB}$ per UP (mutual fund prices) in the year $\mathrm{t}$

$\mathrm{NAB} / \mathrm{UP}_{(\mathrm{t}-1)}=\mathrm{NAB}$ per UP (mutual fund prices) in the year $\mathrm{t}-1$

The tenure variable is measured by the length of service of the head of the investment management team in the investment fund sector which is the research sample measured in units of years.

$$
\mathrm{Te}=\operatorname{Ln}(\mathrm{Te})
$$


The measurement of portfolio turnover variable uses the lowest purchase value or the lowest sales portfolio (selected one of the lowest) in one period and then compared with the average value of Asset Under Management (AUM) in one year (Dahlquist et al. 2000).

$$
\text { Portfolio Turnover (TR): } \frac{\text { Buy/ Sell (lower) }}{\text { average } \mathrm{NAB}_{\mathrm{t}}}
$$

The measurement of market timing and stock selectivity variables uses the Treynor-Mazuy Model. The assumption is that the mutual fund investment management team has a market timing value greater than $0(\beta 2>0)$, meaning that the mutual fund investment management team has Market timing capabilities, and vice versa. If the result of $\beta 2$ is positive and has a significant value, this indicates that the investment manager has a market timing ability. But if the $\beta 2$ result is negative, then this indicates that the mutual fund investment management team does not have market timing capabilities. From the conclusions above, the $\beta 2$ value is a reflection of the level of sensitivity of stock returns to changes in market return. And the assumption for stock selectivity is that if the alpha results are positive and significant, the mutual fund investment management team has stock selectivity capabilities. Alpha value is a description of the level of sensitivity of stock returns to changes in market return.

Treynor and Mazuy (1966) measures market timing by adding a quadratic term to the Jensen $(1968,1969)$ model to capture the timing skills of fund managers (Treynor et al. 1966). Their model is presented below as equation:

$$
\mathrm{R}_{\mathrm{i}}-\mathrm{R}_{\mathrm{f}}=\alpha_{1}+\beta_{1} \cdot\left(\mathrm{R}_{\mathrm{m}}-\mathrm{R}_{\mathrm{f}}\right)+\beta_{2} \cdot\left(\mathrm{R}_{\mathrm{m}}-\mathrm{R}_{\mathrm{f}}\right)^{2}+\hat{\mathrm{e}}_{\mathrm{p}}
$$

In which:

$\mathrm{R}_{\mathrm{i}}=$ mutual fund portfolio return,

$\mathrm{R}_{\mathrm{f}}=$ return for risk free assets,

$\mathrm{R}_{\mathrm{m}}=$ return from the stock market,

$\alpha=$ intercept stock selection indications,

$\beta_{1}=$ regression coefficient of excess market return or slope at time

market down (bearish),

$\beta_{2}=$ Regression coefficient indicator of market timing capability

$\hat{\mathrm{e}}_{\mathrm{p}}=$ error term.

To test the role of mutual funds performance on the firm value uses panel data regression model as follows:

$$
\text { Sharpe Ratio }=\beta 0+\beta 1 \mathrm{TE}+\beta 2 \mathrm{TO}+\beta 3 \mathrm{MT}+\beta 4 \mathrm{SL}+\varepsilon 1
$$

\section{Empirical Results}

Table 3 provides the descriptive statistics for the independent variables used in the study over the period 2013 to 2017.

Table 3. Summary descriptive statistics for the independent variables

\begin{tabular}{llllll}
\hline Variable & Mean & Median & Max & Min & Std Dev \\
\hline Tenure & 19,8 & 20 & 33 & 9 & 7,280 \\
\hline Turnover portfolio & 1,042 & 0,800 & 4,960 & 0,098 & 0,926 \\
\hline Market timing & 0,015 & 0,007 & 0,532 & $-0,440$ & 0,087 \\
\hline Stock selectivity & 3,129 & 2,740 & 19,568 & $-5,138$ & 5,244 \\
\hline
\end{tabular}

The testing data in this study is to assess the Goodness of Fit model by using jarque bera for data normality, multicollinity and durbin waston tests for autocorrelation tests. The test results of Goodness of Fit mode using indicators can be seen in Table 4 . The results as seen in table 4 show that all indexes of goodness of fit structured are fit models. This is seen from the model results value, which is appropriate by the cut off value description. 
Table 4. The test results of goodness of fit model

\begin{tabular}{lllll}
\hline Model fit indicator & Value & Cut off value & Conclusion \\
\hline Normality & Jarque-Bera & JB value $=4,206$ & $\mathrm{P}>5 \%$ & Model fit \\
& & Prob. $=0,122$ & & \\
\hline Multicolinearity & Correlation & Correlation $>0,70$ & Correlation $>0,70$ & Model fit \\
\hline Autocorrelation & Durbin Watson & DW $=3,273$ & $1,679<\mathrm{DW}<3.679)$ & Model fit \\
\hline
\end{tabular}

This paper adopts the ordinary least square (OLS) method of estimation instead to estimate the panel data regression formed. Since a model with random effect displays autocorrelation problem (Gujarati, 2003), this paper estimates the model using the ordinary least square (OLS) effect. Table 3 reports the regression results estimation incorporating mutual fund managers' characteristics and mutual funds charactistic on the performance. Based on the calculation through path analysis done by using eviews which covers mutual funds performance, tenure, turnover portfolio, market timing and stock selectivity.

Tabel 5. Direct influence of tenure, turnover portfolio, market timing, stock selectivity and sharpe ratio

\begin{tabular}{lllll}
\hline Variable & Coefficient & Std. Error & t-Statistic & Prob. \\
\hline Turnover portfolio & 1.028 & 0.419 & 2.452 & $0.016^{*}$ \\
\hline Tenure & -0.017 & 0.962 & -0.018 & 0.986 \\
\hline Market timing & 21.332 & 4.637 & 4.600 & $0.000^{*}$ \\
\hline Stock selectivity & 3.923 & 0.567 & 6.922 & $0.000^{*}$ \\
\hline
\end{tabular}

Note: $(*)$ significant at $5 \%,(* *)$ significant at $10 \%$

Source: data processed by eviews

From the table above, the variable turnover portfolio, market timing and stock selectivity affect the performance of mutual funds with a significance below 5\%. Vaiabel tenure has no effect on the performance of equity funds. This is contrary to the theory of Resources Based View Theory. For further proof, in this study tenure will be tested non-linearly about its effect on mutual fund performance. Calculations using non linear equations with equations:

$$
\begin{gathered}
\mathrm{Y}=\mathrm{aX} \mathrm{X}^{2}+\mathrm{bX}+\mathrm{c} \\
\text { Sharpe }=0,007 \mathrm{Te}^{2}-0,270 \mathrm{Te}+5,116
\end{gathered}
$$

The results obtained a value of $0.007, b$ value of -0.270 and $\mathrm{c}$ value of 5.116 . The measurements for extreme points are as follows:

$$
\begin{gathered}
\text { Extreme point }=\left((-b / 2 a),\left(b^{2}-4 a c /-4 a\right)\right) \\
\text { Extreme point }=(19,268 ; 2,1)
\end{gathered}
$$

From the calculation of values $\mathrm{a}, \mathrm{b}$ and $\mathrm{c}$ are then entered into measurements to find the peak point (extreme point), the peak point value obtained at the ordinate point of tenure is 19.3 and the mutual fund performance value is $2.1 \mathrm{x}$. From this value it is known that the value of a $<0$, this states that the curve is open down.

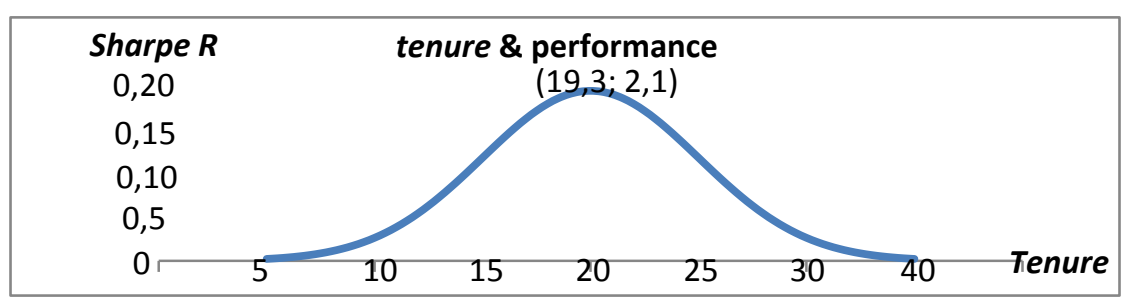

Figure 1. Non-linear relationship between tenure and mutual fund performance 
The extreme point of the equation is 19.3 years. From this data tenure data will be divided into 2 groups, with group 1 being tenure under 19 years, and group 2 being tenure over 19 years. Group 1 data obtained 66 data, and group 2 data 69 data. Then each group will be analyzed its effect on mutual fund performance using the eviews tool. Based on the calculation through path analysis done by using eviews which includes mutual funds performance and tenure, which are divided into 2 groups, namely under 19 years and over 19 years.

Table 6. Mutual funds performance and tenure below and above 19 years

\begin{tabular}{llllll}
\hline Variable & Coefficient & Std. Error & t-Statistic & Prob. \\
\cline { 2 - 5 } Tenure below 19 years & 0.211 & 0.166 & 1.269 & 0.209 \\
\hline Tenure above 19years & 0.248 & 0.149 & 1.663 & $0,100^{* *}$ \\
\hline
\end{tabular}

Note: $(*)$ significant at $5 \%,(* *)$ significant at $10 \%$

Based on the results of the data above, tenure under 19 years has no effect on mutual fund performance, whereas tenure over 19 years has an influence on the performance of equity funds, with a significance of $10 \%$. This shows that investment managers in Indonesia who have worked more than 19 years have been able to adjust market conditions with the management of the equity fund portfolio. Considering the stock market in Indonesia, the period of 2013 to 2017 experienced a significant upheaval, which dropped sharply in 2013 and 2015. This was because in 2013 Indonesia was affected by global conditions, namely the pressure resulting from reversal of market sentiment was mainly triggered by increasing market players' concerns about the sustainability stimulus policy from the Fed. And 2015 was affected by two things, namely the domestic side because the pace of the domestic economy was unable to meet expectations, whereas previously market participants had high hopes for the new government, and the external side was the plan to normalize benchmark interest rates by the Federal Reserve as the central bank US. The results show that in tenure over 19 years, investment managers have a better experience and face the stock market in Indonesia between 2013 and 2017. This is in accordance with the theory of Resources Based View (RBV), which states that the ability of employees that can be measured by the length of service of these employees can increase company performance.

The results showed that there was no influence of the tenure period with the performance of equity funds in Indonesia from 2013 to 2017. This is in line with Boyson's research which states tenure will damage the performance of hegde funds, because more experienced managers are more conservative because they have more loss in terms of personal wealth, current income, and reputation (Boyson, 2003). The results of this study also showed that tenure above 19 years had a significant positive effect on mutual fund performance, but not with tenure under 19 years. This indicates that the investment fund management team in Indonesia with a tenure of less than 19 years has not been able to cope with fluctuations in Indonesia's stock investment. They do not have good experience to overcome this, so mutual fund performance has not been able to improve. In contrast to tenure over 19 years, this employee has been able to cope with fluctuations and is able to produce high mutual fund performance. This relationship can be an indication of agent conflict, given that tenure managers can reflect specific knowledge about the markets in which they operate (Malaquias and Junior 2014). In addition, the most experienced managers are usually older than the least experienced, have generally been recognized by the market, and tend to be more conservative, perhaps because they have continued to implement some correct strategies and routines in the past (Naidenova et al. 2015).

\section{Conclusion}

This paper examines the effects of mutual funds and mutual funds managers' characteristics on fund performance. The results showed that there was no influence of the tenure period with the performance of equity funds in Indonesia from 2013 to 2017. The results of this study also showed that tenure above 19 years had a significant positive effect on mutual fund performance, but not with tenure under 19 years. This indicates that the investment fund management team in Indonesia with a tenure of less than 19 years has not been able to cope with fluctuations in Indonesia's stock investment.

This study concluded that investment strategies affect the performance of equity funds in Indonesia from 2013 to 2017. An active investment strategy with a high portfolio turnover proxy will improve the performance of equity funds. This is in line with the theory of efficient-market hypothesis (EMH) where in inefficient markets like Indonesia, there will be an abnormal return due to lack of information on the market, so investment managers are guided to always adjust the market by making a high portfolio turnover. Other variables of investment strategies are 
market timing and stock selectivity which have a positive influence on the performance of equity funds and the strategy of choosing the right securities with the strategy of choosing the right time to allocate securities into the mutual fund portfolio so that it will improve mutual fund performance. The empirical results are important in supporting modern portfolio theory, where the greater the risk borne, it will increase the return received. The risks involved in carrying out investment strategies in the form of portfolio turnover, market timing and stock selectivity will remind the performance of equity funds in Indonesia. Responding to the condition of the Indonesian market, it is appropriate to use the active mutual fund investment strategy.

Theoretically, the findings have implications in strengthening and supporting Markowitz's modern portfolio theory. In practical terms, the implications of the study's findings reveal that portfolio turnover is an active investment strategy that is suitable to be applied in equity funds in Indonesia, given Indonesia's stock market is still less efficient. The second practical implication, the selection of appropriate mutual fund shares can be traced to the tenure of the head of the investment management team who are high above 19 years, where the tenure is considered to have mastered market knowledge. Third, the ability of investment managers can be improved by training

This study has several limitations. First, the measurement of tenure in this study uses tenure data from the head of the investment management team in units of years, and does not use other measurement methods. Second, there are quite a few research objects because some stock mutual funds have not yet published their financial statements continuously by investment managers

Future studies are suggested to extend the research period, examine the effect of investment manager characteristics on mutual fund performance in addition to stock mutual funds, measure tenure with other measurement methods and examine other variables that support mutual fund performance.

\section{References}

Auw, E. (2009). Human capital, capabilities and competitive advantage. International Review of Business Research Papers, 5(5), 25-36.

Baker, M., Litov, L., Wachter, J. A., \& Wurgler, J. (2010). Can mutual fund managers pick stocks? Evidence from their trades prior to earnings announcements. Journal of Financial and Quantitative Analysis, 45(5), 1111-1131. https://doi.org/10.1017/S0022109010000426

Boyson, N. M. (2003). Why do experienced hedge fund managers have lower returns. Working Paper, Purdue University, West Lafayette.

Brinson, G. P., Hood, L. R., \& Beebower, G. L. (1986). Determinants of portfolio performance. Financial Analysts Journal, 42(4), 39-44. https://doi.org/10.2469/faj.v42.n4.39

Cao, C., Simin, T. T., \& Wang, Y. (2013). Do mutual fund managers time market liquidity?. Journal of Financial Markets, 16(2), 279-307. https://doi.org/10.1016/j.finmar.2012.10.004

Carhart, M. M. (1997). On persistence in mutual fund performance. The Journal of Finance, 52(1), 57-82. https://doi.org/10.1111/j.1540-6261.1997.tb03808.x

Champagne, C., Karoui, A., \& Patel, S. (2018). Portfolio turnover activity and mutual fund performance. Managerial Finance, 44(3), 326-356. https://doi.org/10.1108/MF-01-2017-0003

Cremers, K. M., \& Petajisto, A. (2009). How active is your fund manager? A new measure that predicts performance. The Review of Financial Studies, 22(9), 3329-3365. https://doi.org/10.1093/rfs/hhp057

Cremers, M., \& Pareek, A. (2016). Patient capital outperformance: The investment skill of high active share managers who trade infrequently. Journal of Financial Economics, 122(2), 288-306. https://doi.org/10.1016/j.jfineco.2016.08.003

Dahlquist, M., Engström, S., \& Söderlind, P. (2000). Performance and characteristics of Swedish mutual funds. Journal of Financial and Quantitative Analysis, 35(3), 409-423. https://doi.org/10.2307/2676211

de Mingo-López, D. V., \& Matallín-Sáez, J. C. (2018). Institutional investment management: An investor's perspective on the relation between turnover and performance. Investment Analysts Journal, 47(2), 81-94. https://doi.org/10.1080/10293523.2017.1414370

Dyck, A., Lins, K. V., \& Pomorski, L. (2013). Does active management pay? New international evidence. The Review of Asset Pricing Studies, 3(2), 200-228. https://doi.org/10.1093/rapstu/rat005 
Eacott, S. (2010). Tenure, functional track and strategic leadership. International Journal of Educational Management, 24(5), 448-458. https://doi.org/10.1108/09513541080000454

Golec, J. H. (1996). The effects of mutual fund managers' characteristics on their portfolio performance, risk and fees. Financial Services Review. https://doi.org/10.1016/S1057-0810(96)90006-2

Grinblatt, M., \& Titman, S. (1993). Performance measurement without benchmarks: An examination of mutual fund returns. Journal of Business, 66(1), 47-68. https://doi.org/10.1086/296593

Harris, C. (2009). Strategic human resource management at the crossroads: Relationships among human resource capital, overlapping tenure, behaviors, and performance. Dissertation, The University of Texas at Arlington.

Henriksson, R. D., \& Merton, R. C. (1981). On market timing and investment performance. II. Statistical procedures for evaluating forecasting skills. Journal of Business, 513-533. https://doi.org/10.1086/296144

Hochberg, Y. V., \& Muhlhofer, T. (2011). Market timing and investment selection: Evidence from real estate investors. https://doi.org/10.2139/ssrn.1785800

Hu, J. L., \& Chang, T. P. (2008). Decomposition of mutual fund underperformance. Applied Financial Economics Letters, 4(5), 363-367. https://doi.org/10.1080/17446540701720675

Ippolito, R. A. (1989). Efficiency with costly information: A study of mutual fund performance, 1965-1984. The Quarterly Journal of Economics, 104(1), 1-23. https://doi.org/10.2307/2937832

Kapoor, A. (2010). Performance Comparison of Canadian Hedge Funds and Mutual Funds. Master thesis, Simon Fraser University.

Khajar, I. (2011). Strategi Aktif Pasif Dalam Optimalisasi Portofolio Saham Indeks LQ-45. Jurnal Keuangan dan Perbankan, 15(2).

Khorana, A., Wahal, S., \& Zenner, M. (2002). Agency conflicts in closed-end funds: The case of rights offerings. Journal of Financial and Quantitative Analysis, 37(2), 177-200. https://doi.org/10.2307/3595002

Kremnitzer, K. (2012). Comparing active and passive fund management in emerging markets. Senior Honors Thesis, Economics Department, University of California, Berkeley.

Laes, M. A., \& da Silva, M. E. (2014). Performance of mutual equity funds in Brazil - A bootstrap analysis. Economia, 15(3), 294-306. https://doi.org/10.1016/j.econ.2014.08.002

Lee, J. S., Yen, P. H., \& Chen, Y. J. (2008). Longer tenure, greater seniority, or both? evidence from open-end equity mutual fund managers in taiwan. Asian Academy of Management Journal of Accounting \& Finance, 4(2), 1-20.

Li, H., Zhang, X., \& Zhao, R. (2011). Investing in talents: Manager characteristics and hedge fund performances. Journal of Financial and Quantitative Analysis, 46(1), 59-82. https://doi.org/10.1017/S0022109010000748

Liu, Y., \& Ravichandran, T. (2007). Information Technology Capital, Managerial Human Capital, and Firm Performance: An Empirical Investigation. Proceedings of the Fifteenth European Conference on Information Systems (pp. 994-1006). St. Gallen, Switzerland..

Lubis, T. A. (2010). Analisis Kinerja Reksadana Saham dan Reksadana Indeks dalam Penilaian Tingkat Efisiensi Pasar Modal Indonesia. Wacana, Jurnal Sosial dan Humaniora, 13(2), 289-300.

Maestri, C. O. N. M., \& Malaquias, R. F. (2018). Aspects of manager, portfolio allocation, and fund performance in Brazil. Revista Contabilidade \& Finanças, 29(76), 82-96. https://doi.org/10.1590/1808-057x201804590

Malaquias, R. F., \& Junior, W. E. (2014). Fundos multimercados: desempenho, determinantes do desempenho e efeito moderador. Revista de Administração Mackenzie (Mackenzie Management Review), 15(4). https://doi.org/10.1590/1678-69712014/administracao.v15n4p135-163

Malkiel, B. G., \& Fama, E. F. (1970). Efficient capital markets: A review of theory and empirical work. The Journal of Finance, 25(2), 383-417. https://doi.org/10.1111/j.1540-6261.1970.tb00518.x

Manek, V. B. (2016). Mutual fund performance: a study on the effect of portfolio turnover on mutual fund performance in the indian financial market. Scholarly Research Journal for Interdisciplinary Studies, 3(23),1916-1926.

Naidenova, I., Parshakov, P., Zavertiaeva, M., \& Tome, E. (2015). Look for people, not for alpha: mutual funds success and managers intellectual capital. Measuring Business Excellence, 19(4), 57-71. https://doi.org/10.1108/MBE-11-2014-0039 
Nanda, V., Narayanan, M. P., \& Warther, V. A. (2000). Liquidity, investment ability, and mutual fund structure. Journal of Financial Economics, 57(3), 417-443. https://doi.org/10.1016/S0304-405X(00)00063-5

Narayanamoorthy, V., \& Rao, K. (2012). The Relationship between Fund Performance and Fund Characteristics: Evidence from India.

Pangestuti, I. R. D., Wahyudi, S., \& Robiyanto, R. (2017). Performance Evaluation of Equity Mutual Funds in Indonesia. Jurnal Keuangan dan Perbankan, 21(4). https://doi.org/10.26905/jkdp.v21i4.1503

Pástor, L., Stambaugh, R. F., \& Taylor, L. A. (2015). Scale and skill in active management. Journal of Financial Economics, 116(1), 23-45. https://doi.org/10.1016/j.jfineco.2014.11.008

Patterson, P. G., Johnson, L. W., \& Spreng, R. A. (1996). Modeling the determinants of customer satisfaction for business-to-business professional services. Journal of the Academy of Marketing Science, 25(1), 4-17. https://doi.org/10.1177/0092070397251002

Payne, T. H., Prather, L., \& Bertin, W. (1999). Value creation and determinants of equity fund performance. Journal of Business Research, 45(1), 69-74. https://doi.org/10.1016/S0148-2963(98)00059-9

Persson, M., \& Karlsson, T. (2005). Mutual fund performance-Explaining the performance of Swedish domestic equity mutual funds using different fund characteristics.

Petty, R., \& Guthrie, J. (2000). Intellectual capital literature review: measurement, reporting and management. Journal of Intellectual Capital, 1(2), 155-176. https://doi.org/10.1108/14691930010348731

Philpot, J., Hearth, D., \& Rimbey, J. (2000). Performance persistence and management skill in nonconventional bond mutual funds. Financial Services Review, 9(3), 247-258. https://doi.org/10.1016/S1057-0810(00)00066-4

Poole, B. S., Bianco, C. A., \& Giroux, C. (2006). Mutual fund management and fund performance. Journal of Business \& Economics Research (JBER), 4(1). https://doi.org/10.19030/jber.v4i1.2621

Porter, G. E., \& Trifts, J. (2012). The best mutual fund managers: Testing the impact of experience using a survivorship bias free dataset. Journal of Applied Finance (Formerly Financial Practice and Education), 22(1).

Putra, L. L., Murhadi, W. R., \& Mahadwartha, P. A. (2013). Strategi aktif (moving average) dan strategi pasif (buyand-hold strategi) pada pembentukan portofolio periode 2 januari 2012-28 desember 2012. Calyptra Jurnal Manajemen Teori dan Terapan, 2(2), 1-13.

Rao, D. N. (2010). Portfolio Turnover and its Effect on Performance of Equity-Oriented Mutual Fund Schemes: An Empirical Study in the Indian Context. https://doi.org/10.2139/ssrn.1549878

Robiyanto, R., Santoso, M. A., \& Ernayani, R. (2019). Sharia mutual funds performance in Indonesia. Business: Theory and Practice, 20, 11-18. https://doi.org/10.3846/btp.2019.02

See, Y. P., \& Jusoh, R. (2012). Fund characteristics and fund performance: Evidence of Malaysian mutual funds. International Journal of Economics and Management Sciences, 1(9), 31-43.

Swinkels, L., \& Rzezniczak, P. (2009). Performance evaluation of Polish mutual fund managers. International Journal of Emerging Markets, 4(1), 26-42. https://doi.org/10.1108/17468800910931652

Treynor, J., \& Mazuy, K. (1966). Can mutual funds outguess the market. Harvard Business Review, 44(4), 131-136.

Wermers, R. (2000). Mutual fund performance: An empirical decomposition into stock-picking talent, style, transactions costs, and expenses. The Journal of Finance, 55(4), 1655-1695. https://doi.org/10.1111/0022-1082.00263

Wiksuana, I. G. B. (2009). Kinerja Portofolio Saham Berdasarkan Strategi Investasi Momentum di Pasar Modal Indonesia. Jurnal Manajemen dan Kewirausahaan, 11(1), 73-84.

Wu, S.-C. (2014). Interaction between mutual fund performance and portfolio turnover. Journal of Emerging Issues in Economics, 3(4), 1125-1140. 